\title{
CONTRIBUTION OF MACROPOROSITY TO WATER FLUX OF A SOIL UNDER DIFFERENT TILLAGE SYSTEMS ${ }^{(1)}$
}

\author{
Carlos Germán Soracco ${ }^{(2)}$, Luis Alberto Lozano ${ }^{(2)}$, Roberto Balbuena ${ }^{(2)}$, Juan Manuel \\ Ressia $^{(3)}$ \& Roberto Raúl Filgueira ${ }^{(4)}$
}

\begin{abstract}
SUMMARY
In view of the importance of the macroporosity for the water transport properties of soils, its quantitative assessment is a challenging task. Measurements of hydraulic conductivity $(\mathrm{K})$ at different soil water tensions and the quantification of water-conducting macropores $\left(\theta_{\mathrm{M}}\right)$ of a soil under different tillage systems could help understand the effects on the soil porous system and related hydraulic properties. The purpose of this study was to assess the effects of Conventional Tillage (CT), Chisel Plow (CP) and No Tillage (NT) on $\theta_{M}$ and on K; and to quantify the contribution of macroporosity to total water flux in a loam soil. A tension disc infiltrometer was used at two soil water pressure heads $(-5 \mathrm{~cm}$, and 0$)$ to infer $\theta_{M}$ and $\mathrm{K}$, during fallow. Macroporosity was determined based on the flow contribution between 0 and $-5 \mathrm{~cm}$ water potentials $\left(K_{0}, K_{5}\right.$, respectively), according to the HagenPoiseuille equation. The $K_{0}$ values were statistically higher for CT than for NT and $C P$. The $K_{5}$ values did not differ statistically among treatments. The mean $K$ values varied between 0.20 and $3.70 \mathrm{~cm} / \mathrm{h}$. For CT, $\theta_{M}$ was significantly greater than for CP and NT, following the same trend as $K_{0}$. No differences in $\theta_{M}$ were detected between CP and NT. With CT, the formation of water-conducting macropores with persistence until post-harvest was possible, while under CP preparation, the waterconducting macropores were not persistent. These results support the idea that tillage affects the soil water movement mainly by the resulting water-conducting macropores. Future studies on tillage effects on water movement should focus on macroporosity.
\end{abstract}

Index terms: Tension disc infiltrometer, no tillage, chisel plow, conventional tillage, effective porosity.

(1) Received for publication in November 17, 2011 and approved in May 18, 2012.

(2) Research Fellow of the Consejo Nacional de Investigaciones Científicas y Técnicas (CNICT), Facultad de Ciencias Agrarias y Forestales (FCAF), UNLP. Calles 60 y 119, CC 31. 1900 La Plata, Argentina. E-mail: germansoracco@yahoo.com.ar; fisica@agro.unlp.edu.ar

(3) Facultad de Agronomía, UNICEN. República de Italia 780, CP 7300. Azul, Argentina. E-mail: jmressia@faa.unicen.edu.ar

(4) Scientific Researcher of the CNICT, FCAF, UNLP, 1900 La Plata, Arentina. E-mail: rrfilgueira@gmail.com 


\title{
RESUMO: CONTRIBUIÇÃO DA MACROPOROSIDADE PARA O FLUXO TOTAL DE ÁGUA EM UM SOLO SOB DIFERENTES SISTEMAS DE PREPARO
}

\begin{abstract}
A importância da macroporosidade para o transporte de água no solo faz a sua avaliação de forma quantitativa uma tarefa desafiadora. Os valores da condutividade hidráulica (K) do solo em diferentes potenciais de retenção de água no solo e a quantificação de macroporos condutores de água $\left(\theta_{M}\right)$ em diferentes sistemas de preparo do solo proporcionarão melhor compreensão dos efeitos no arranjo de poros e nas propriedades físico-hídricas do solo. Dessa forma, o objetivo deste estudo foi avaliar os efeitos de um preparo convencional do solo com arado de aivecas (CT), com subsolador (CP) e utilizando um sistema com plantio direto (NT) sobre os atributos $\theta_{M}$ e $K$, bem como quantificar a contribuição da macroporosidade para o fluxo total de água em um solo franco. Um infiltrômetro de tensão no solo foi utilizado para emitir duas pressões ascendentes de água $(-5 \mathrm{~cm}$ e $0 \mathrm{~cm})$ para inferir $\theta_{M} e K$, durante o pousio. A macroporosidade foi determinada com base na contribuição do fluxo entre os potenciais de água de 0 e $-5 \mathrm{~cm}\left(K_{0}\right.$ e $K_{5}$, respectivamente), de acordo com a equação de Hagen-Poiseuille. Os valores da $K_{0}$ obtidos foram estatisticamente superiores no preparo $C T$, quando comparados aos valores do NT e do CP. Os valores da $K_{5}$ não diferiram estatisticamente entre os tipos de preparo. Os valores médios da $K$ variaram entre 0,20 e $3,70 \mathrm{~cm} / \mathrm{h}$. A quantificação de macroporos condutores de água $\left(\theta_{M}\right)$ foi significativamente superior para o preparo $C T$ em relação aos preparos $C P$ e NT, seguindo a mesma tendência da $K_{0}$. Não foram detectadas diferenças significativas dos valores de $\theta_{M}$ entre os preparos CP e NT. Utilizando o preparo $C T$, foi possível a formação de macroporos condutores de água com persistência até a póscolheita; já no preparo $C P$, os macroporos condutores de água não foram persistentes. Os resultados apresentados sustentam a hipótese de que o sistema de preparo do solo escolhido altera o movimento da água no solo, principalmente, devido à formação de macroporos condutores de água. Estudos futuros sobre o efeito do sistema de preparo relacionado ao movimento da água no solo devem-se concentrar nas condições de formação da macroporosidade do solo.
\end{abstract}

Termos de indexação:Infiltrômetro de tensão, plantio direto, subsolagem, preparo convencional, porosidade efetiva.

\section{INTRODUCTION}

The agricultural areas under no tillage (NT) have been continuously increasing in the last few years. In 1999 , NT was used on about $450,000 \mathrm{~km}^{2}$ worldwide, increasing to $720,000 \mathrm{~km}^{2}$ in 2003 , and to 1050,000 $\mathrm{km}^{2}$ in 2009. The adoption rates of no-tillage systems have been highest in South America. Argentina is among the countries with an area as large as 200,000 $\mathrm{km}^{2}$ under NT, representing about $70 \%$ of the whole cultivated area of the country (Kassam et al., 2009).

Time and cost savings as well as soil conservation were the main driving forces for the widespread adoption of NT in Argentina since the 1990s (Álvarez et al., 2009a). Some authors have found that the replacement of Conventional Tillage (CT) by NT farming in Argentina and in other temperate regions of the world has resulted in better erosion control, water conservation, and nutrient cycling, time savings, reduction in the use of fossil fuels, and increased soil C sequestration (Díaz-Zorita et al., 2002; Bolliger et al., 2006; Steinbach \& Álvarez 2006; Lal et al., 2007; Thomas et al., 2007; Strudley et al., 2008). However, the effect of adoption of NT on soil physical properties was not always consistent across locations, soils and experimental designs (Green et al., 2003; Strudley et al., 2008).

Some studies in Argentina stated a decrease in total porosity (TP) and greater bulk density (BD) under NT than CT (Ferreras et al., 2000; Elissondo et al., 2001; Díaz-Zorita et al., 2002; Fabrizzi et al., 2005; Costantini et al., 2006; Sasal et al., 2006). The compaction associated with NT affects the soil porosity, resulting in a reconfiguration of the porous system (Horton et al., 1994; Strudley et al., 2008). Strudley et al. (2008) reviewed tillage effects on soil hydraulic properties in space and time. They concluded that NT would increase macropore connectivity, while inducing no changes in TP and $\mathrm{BD}$, compared with CT.

Several studies investigated the infiltration rate in soils under NT, with contradictory results. Some found that soils under NT have higher infiltration rates than under CT (Benjamin, 1993; Baumhardt \& Lascano, 1996; Quiroga et al., 1998; Sanzano et al., 2005; Steinbach \& Álvarez, 2007). Other studies reported lower infiltration rates in soils under NT than under CT (Ross \& Hughes, 1985; Alegre et al., 1991; Horne et al., 1992; Azoos \& Arshad, 1996; Ferreras et al., 2000; Alvarez et al., 2006). In soils of the Rolling 
Pampa, Álvarez et al. (2009a) found that infiltration rates varied differently in loam $(\mathrm{NT} \approx \mathrm{CT})$ from silt loam and silty clay loam (NT $<<\mathrm{CT}$ ) soils. In the silt loam and silty clay loam group, the water infiltration rate was approximately four times higher than at CT sites. Sasal et al. (2006) found higher or similar infiltration rates in a silt loam soil from the Rolling Pampa under Chisel Plow (CP) than under NT, depending on the crop rotation. Wahl et al. (2004) found that the saturated hydraulic conductivity $\left(\mathrm{K}_{0}\right)$ of a silty loam soil was similar under conventional tillage and conservation tillage. In all cases, the soils were under NT for at least 5 years, the minimum period cited as necessary for the stabilization of several soil properties (Álvarez et al., 2009a). Horton et al. (1994) emphasized that a more comprehensive understanding about effects of soil management practices on soil hydraulic properties is needed.

The measurements of hydraulic conductivity (K) at different soil water tensions and the quantification of water-conducting macroporosity $\left(\theta_{\mathrm{M}}\right)$ are important to improve the understanding of soil physical behavior. The properties of the soil macropore network, i.e. macropore volume fraction, diameter and continuity of macropores, have a great impact on the infiltration characteristics of agricultural soils (Hillel, 1998). Studies to quantify macropore flow revealed that more than $70 \%$ of the water flux can move through macropores (Watson \& Luxmoore, 1986; Wilson \& Luxmoore, 1988). In general, the water flow through structured soils is mainly conducted by macropores even though these constitute only a very small fraction of total porosity (Cameira et al., 2003). Macroporosity represents an important indicator of soil physical quality, particularly in relation to the site-specific water transmission properties, and can be used as a sensitive measure to assess soil structural degradation. The importance of soil macroporosity for the water transport properties of the soil still makes its quantitative assessment a challenging task (Bodner et al., 2010).

The tension disc infiltrometer is a valuable tool to investigate the water movement through macropores and the soil matrix near saturation (Watson \& Luxmoore, 1986; Logsdon \& Jaynes 1993; Moret \& Arrúe, 2007), and to study the effects of soil tillage practices on the soil surface hydraulic properties (Malone et al., 2003; Moret \& Arrúe, 2007). This device allows the estimation of $K$ from saturation to a very low suction head (Angulo-Jaramillo et al., 2000) and quantifies the role of macropores during infiltration (Bodhinayake et al., 2004). This technique requires only minimal soil disturbance. Measurements of $\mathrm{K}$ at different soil water tensions, and quantification of $\theta_{\mathrm{M}}$ of a soil under different tillage managements could help understand the effects of these practices on the soil porous system and related hydraulic properties.

It was hypothesized that the tillage system affects $\mathrm{K}$ and $\theta_{\mathrm{M}}$ values obtained in field measurements with a tension disc infiltrometer, being higher for $\mathrm{CT}$ and CP than for NT.

The objectives of this study were: i) to assess the effects of different tillage systems on water-conducting macroporosity and on hydraulic conductivity; and ii) to quantify the contribution of macroporosity to total water flux.

\section{MATERIALS AND METHODS}

\section{Site and treatments}

The experiment was carried out near the town of Azul, Argentina. The soil was classified as a fine, mixed, thermic Petrocalcic Paleudoll (USDA, 2006), Luvic Phaeozem (IUSS Working Group WRB, 2006). The A horizon had a loamy texture.

On the studied plots $\left(36^{\circ} 42^{\prime} \mathrm{S}\right.$ and $\left.59^{\circ} 50^{\prime} \mathrm{W}\right)$, the treatments below and the same 2 -yr crop sequence of maize (first year)-wheat and short-season soybean (second year) had been applied over 10 years. The climate in the region is temperate (temperatures rarely below $0{ }^{\circ} \mathrm{C}$ ) and the approximate annual rainfall $1,000 \mathrm{~mm}$. The experiment was arranged in a complete randomized block design with three treatments: a) conventional tillage (CT), in which the soil was moldboard-plowed to a depth of $0.19 \mathrm{~m}$ and disk- and tooth-harrowed to $0.10 \mathrm{~m}$ each year, b) chisel plow (CP) in which the soil was chiseled to a depth of $0.30 \mathrm{~m}$ (distance between chisel shanks: $0.35 \mathrm{~m}$ ) and disk- and tooth-harrowed to $0.10 \mathrm{~m}$ each year, and (c) no tillage (NT), in which only a narrow $(0.05 \mathrm{~m})$ strip of the soil was drilled to sow crop seeds. There were three plots of $(30 \times 70 \mathrm{~m})$ per treatment.

Soil bulk density (BD) was measured using the core method (Blake \& Hartge, 1986). Undisturbed soil samples (height $10 \mathrm{~cm}$, diameter $7 \mathrm{~cm}$ ) were collected from the first $10 \mathrm{~cm}$ of each plot, near the infiltration points, avoiding plant rows and wheel tracks. Five replicates from each plot were collected ( 15 samples from each treatment, a total of 45 samples). Total porosity (TP) was calculated from $\mathrm{BD}$, assuming a particle density of $2.65 \mathrm{Mg} / \mathrm{m}$ which is normal for mineral soils (Hillel, 1998), and close to values measured for similar soils in the Pampas region (Cosentino \& Pecorari, 1992). Disturbed soil from the same depth was sampled in plastic bags to determine the soil particle size distribution using the pipette method (Gee \& Bauder, 1986) and to determine the organic matter content by the Walkley-Black method (Walkley \& Black, 1934).

\section{In-situ infiltration test}

A tension disc infiltrometer (Perroux \& White, 1988) was used to determine the steady-state infiltration rate. The infiltration tests were carried out during fallow (August), four months after soybean harvest. 
The infiltrometer disc had a base radius of 6.25 $\mathrm{cm}$. Infiltration was measured at four randomly selected sites of each plot (12 replicates per treatment), avoiding plant rows and wheel tracks. To consider only the effects of tillage on soil water infiltration, the crop residues were removed from the soil surface. To ensure good hydraulic contact between the device and the soil, the surface was flattened with a spatula and a thin dry sand layer was spread on it. Infiltration runs were performed at two values of soil water pressure head, h (namely, -5 , and $0 \mathrm{~cm}$, applied in this order and at the same place). This sequence of supply water pressure heads was adopted, because a descending order may cause hysteresis, with progressive drainage occurring close to the disk while wetting continues at the infiltration front (Jarvis \& Messing, 1995). Flow monitoring was continued until steady-state flow from the disc was attained. The cumulative infiltration was recorded every minute until 10 min, every 5 min until 30 min and every 10 min until the end of the test. When the amount of water entered into the soil did not change with time in four consecutive measurements at $10 \mathrm{~min}$ intervals, steady-state flow was assumed and steadystate infiltration rate was calculated based on the last four measurements. The time required to reach the steady state was around $1.5 \mathrm{~h}$ for each tension.

The soil hydraulic conductivity, $\mathrm{K}$, at the different soil water pressure heads, $h$ (i.e., $K_{5}$, and $K_{0}$ ) was then calculated from the cumulative water infiltration using the multiple-head method (Ankeny et al., 1991).

\section{Water-conducting macroporosity}

The classical capillary rise equation allows an approximation of the maximum water-filled pore size, $r,[L]$ at a specific $h[L]$ :

$$
r=\frac{2 \sigma \cos (\alpha)}{\rho g|h|}
$$

where $\sigma$ is the water surface tension $\left[\mathrm{M} / \mathrm{T}^{2}\right], \alpha$ is the contact angle between water and the pore wall (assumed to be zero), $\rho$ is the water density $\left[\mathrm{M} / \mathrm{L}^{3}\right]$, and $g$ is the acceleration due to gravity $\left[\mathrm{L} / \mathrm{T}^{2}\right]$.

It was assumed that the pores with radii smaller than $r$, calculated from equation (1), are full of water and responsible for the entire water flux under a given water pressure head, and that the pores with radii larger than the value calculated from equation 1 have no contribution to the water flux.

According to equation 1, infiltration at water pressure heads of -5 will exclude pores with diameters of $>0.6 \mathrm{~mm}$. In this study, macropores were defined as pore draining at $\mathrm{h}>-5 \mathrm{~cm}(\mathrm{r}>0.3 \mathrm{~mm})$.

The water-conducting porosity due to pores between two radii $\mathrm{ra}$ and $\mathrm{rb}$ ( $\mathrm{ra} \leq \mathrm{rb}$ ), $\theta$ (ra,rb), (assuming pore radius equals to the minimum pore radius), resulting in a difference in total soil water flux or hydraulic conductivity $\Delta \mathrm{K}$ (ra,rb), is (Watson \& Luxmoore, 1986):

$$
\theta(a, b)=\frac{8 \eta \Delta K(r a, r b)}{\rho g(r a)^{2}}
$$

Since ra is the minimum equivalent pore radius in the range, $\theta$ (ra,rb) is an estimation of the maximum water-conducting porosity, because pore radius (ra) appears in the denominator of equation (2). Implicitly assumed in (2) is a unit hydraulic gradient, i.e. steadystate conditions during infiltration (Wahl et al., 2004).

The contribution to flow of the water-conducting macroporosity, $\varphi(\%)$, was calculated as percentage of total flow occurring between 0 and $-5 \mathrm{~cm}$ water pressure heads.

\section{Statistical analysis}

In order to determine the effect of treatments, $\mathrm{BD}$, $\mathrm{K}_{5}, \mathrm{~K}_{0}, \theta_{\mathrm{M}}$, and $\varphi(\%)$ were analyzed separately (five ANOVAs with treatment as factor) (Sokal \& Rohlf, 1995). When a significant treatment effect was found, Fisher's least significant difference (LSD) test (Sokal $\&$ Rohlf, 1995) was used to compare the means of the different soil management practices. The KolmogorovSmirnov test was applied to determine if replicates of measured quantities within a treatment were normally or lognormally distributed. For all analyses, significance was determined at $\mathrm{p}=0.05$.

\section{RESULTS AND DISCUSSION}

The mean particle size distribution of the A horizon did not differ between plots and showed fractions of $21 \%$ clay, $40 \%$ silt and $39 \%$ sand; the soil was classified as loamy, with an organic matter content of $5.5 \%$.

The statistical frequency distribution of the $K$ data was log-normal, which is usual for this soil property (Bagarello et al., 2006), so the statistical analyses were performed with log-transformed values. The other normally distributed variables were not transformed.

Bulk density and derived TP did not differ significantly among treatments in the $0-10 \mathrm{~cm}$ layer $(p=0.05)$. The mean values and standard errors of $B D$ were: $\mathrm{CT}: 1.21 \pm 0.02 \mathrm{Mg} / \mathrm{m}^{3}$; $\mathrm{CP}: 1.24 \pm 0.03 \mathrm{Mg} / \mathrm{m}^{3}$; NT: $1.22 \pm 0.03 \mathrm{Mg} / \mathrm{m}^{3}$. The values of TP were: CT: $46 \%$; CP: $47 \%$; NT: $46 \%$. This result is in agreement with several reports from the Pampas region, that show that tillage effects of BD do not persist until harvest (Ferreras et al., 2000; Sasal et al., 2006; Álvarez et al., 2006; Álvarez et al., 2009a, b; Soracco et al., 2010).

Table 1 summarizes the statistical parameters of the $\mathrm{K}$ data set, calculated using the Ankeny method (Ankeny et al., 1991). The $\mathrm{K}_{0}$ values obtained were significantly greater $(p=0.05)$ for CT than NT and CP. In Silty-Loam, Silty-Clay Loam and Loam soils of the Pampas region, Âlvarez et al. (2009a) found a 
similar behavior pattern for the Silty-Loam and SiltyClay Loam group, but not for the Loam soils. In their study, the infiltration rates into Silty-Loam and SiltyClay Loam soils were particularly high under CT (around $23 \mathrm{~cm} / \mathrm{h}$ ). Moreover, the ratio between the infiltration rates of CT and NT was 4 . For the Loam soils, they found no differences between CT and NT. This discrepancy could be attributed to differences in the soil type (Argiudolls) and the method (single-ring method). In agreement with our results, Ferreras et al. (2000) found that $K_{0}$ was significantly higher under CT than under NT after harvest for a similar soil. They attributed the low $\mathrm{K}_{0}$ values in both treatments and the lack of recovery under NT to intensive cultivation prior to the experiment. The soil studied here had been intensively cultivated prior to conversion to NT. No-tillage and CP did not differ statistically for $\mathrm{K}_{0}$. In comparisons of CP vs NT of soils of the Pampas region, Sasal et al. (2006) found that the differences in the infiltration rates were associated with the crop rotation, being higher for CP when soybean was the predominant crop. In their study, infiltration rates under NT were the same as those under CP when soybean accounted for only one third of the crop rotation. In this study, soybean occupied a similar proportion of the crop rotation. Moreover, the infiltration rates measured by Sasal et al. (2006) were similar to the values found in this work. Álvarez et al. (2006) found no differences in infiltration rates between NT and vertical tillage after harvest in loam soils of the Pampas region.
The $\mathrm{K}_{5}$ values did not differ significantly among treatments (Table 1). This shows that the waterconducting porosity with radii of $<0.3 \mathrm{~mm}$ did not differ statistically among treatments. This result is in agreement with Kay \& VandenBygaart (2002), who emphasized that soil disturbance by tillage would be expected to result in an increase in the macroporosity of the tilled zone.

Water-conducting macroporosity $\left(\theta_{M}\right)$ was significantly greater for CT than CP and NT, following the same trend as $\mathrm{K}_{0}$ (Table 2). No differences in è were detected between CP and NT. Conventional tillage formed water-conducting macropores that persisted until postharvest, whereas under CP no persistent water-conducting macropores were generated; during fallow, the $\theta_{\mathrm{M}}$ fraction was the same as under NT. For soils under NT it would be expected that traffic-induced compaction may be compensated by progressive creation of macropores from roots and faunal activities with time, but this was not confirmed in this study. This lack of macropore formation under NT was previously reported for similar soils by Sasal et al. (2006). The relative contribution of macroporosity to total water flux was high and similar for all treatments (Table 2). This is in agreement with Cameira et al. (2003), who suggested that water flow of structured soils is mainly conducted by macropores, even though these constitute only a very small fraction of total porosity.

These results support the idea that tillage affects soil water movement mainly through the creation of

Table 1. Hydraulic conductivity values and coefficients of variation (CV) for different treatments and tensions

\begin{tabular}{|c|c|c|c|c|c|c|}
\hline \multirow{2}{*}{ Tension } & \multicolumn{2}{|c|}{ Conventional Tillage } & \multicolumn{2}{|c|}{ Chisel Plough } & \multicolumn{2}{|c|}{ No Tillage } \\
\hline & Average & $\mathbf{C V}$ & Average & $\mathbf{C V}$ & Average & $\mathbf{C V}$ \\
\hline $\mathrm{cm}$ & $\mathrm{cm} / \mathrm{h}$ & $\%$ & $\mathrm{~cm} / \mathrm{h}$ & $\%$ & $\mathrm{~cm} / \mathrm{h}$ & $\%$ \\
\hline 0 & $3.70 \mathrm{a} \dagger$ & 39 & $2.33 \mathrm{~b}$ & 21 & $2.32 \mathrm{~b}$ & 31 \\
\hline 5 & $0.28 \mathrm{a}$ & 62 & $0.20 \mathrm{a}$ & 32 & $0.20 \mathrm{a}$ & 65 \\
\hline
\end{tabular}

$\dagger$ The statistical analyses were performed with log-transformed values. Different letters of each water tension indicate statistically significant differences between treatments (LSD test; $\mathrm{p}=0.05$ ).

Table 2. Total porosity (TP) corresponding to water-conducting macroporosity $\left(\theta_{M}\right)$, total contribution to flow (TF) and contribution to flow of the water-conducting macroporosity $(\varphi)$

\begin{tabular}{ccccccccccc}
\hline $\begin{array}{c}\text { Water-conducting } \\
\text { macroporosity }\end{array}$ & \multicolumn{4}{c}{ Conventional Tillage } & \multicolumn{3}{c}{ Chisel Plough } & & \multicolumn{2}{c}{ No Tillage } \\
\cline { 2 - 10 } & TP & TF & $\varphi$ & TP & TF & $\varphi$ & TP & TF & $\varphi$ \\
\hline & $\%$ & $\mathrm{~cm} / \mathrm{h}$ & $\%$ & $\%$ & $\mathrm{~cm} / \mathrm{h}$ & $\%$ & $\%$ & $\mathrm{~cm} / \mathrm{h}$ & $\%$ \\
$\theta_{\mathrm{M}}$ & $0.009 \mathrm{a} \dagger$ & $3.42 \mathrm{a}$ & $92.4 \mathrm{a}$ & $0.005 \mathrm{~b}$ & $2.13 \mathrm{~b}$ & $91.4 \mathrm{a}$ & $0.005 \mathrm{~b}$ & $2.12 \mathrm{~b}$ & $91.4 \mathrm{a}$ \\
\hline
\end{tabular}

$\dagger$ Different letters indicate statistically significant differences between treatments (LSD test; $\mathrm{p}=0.05$ ). 
water-conducting macropores. Future work on the effect of tillage on water movement should focus on macroporosity.

\section{CONCLUSIONS}

1. The tillage systems affected the values of waterconducting macroporosity and saturated hydraulic conductivity, which were higher under conventional tillage than under chisel plow and no-tillage management.

2. Although tillage affects water-conducting macropores, no effects of tillage were observed on smaller pores.

\section{LITERATURE CITED}

ALEGRE, J.C.; CASSEL, D.K. \& AMEZQUITA, E. Tillage systems and soil properties in Latin America. Soil Tillage Res., 20:147-163, 1991.

ÁLVAREZ, C.R.; TABOADA, M.A.; BUSTINGORRI, C. \& GUTIÉRREZ BOEM, F.H. Descompactación de suelos en siembra directa: Efectos sobre las propiedades físicas y el cultivo de maíz. Ci. Suelo, 24:1-10, 2006.

ÁLVAREZ, C.R.; TABOADA, M.A.; GUTIÉRREZ BOEM, F.H.; BONO, A., FERNANDEZ, P.L. \& PRYSTUPA, P. Topsoil properties as affected by tillage systems in the rolling Pampa Region of Argentina. Soil Sci. Soc. Am. J., 73:12421250, 2009a.

ÁLVAREZ, C.R.; TORRES DUGGAN, M.; CHAMORRO, E.R.; D'AMBROSIO, D. \& TABOADA, M.A. Descompactación de suelos Franco Limosos en siembra directa: Efectos sobre las propiedades edáficas y los cultivos. Ci. Suelo, 27:159-169, 2009b.

ANGULO-JARAMILLO, R.; VANDERVAERE, J.P.; ROULIER, S.; THONY, J.L.; GAUDET, J.P. \& VAUCLIN, M. Field measurement of soil hydraulic properties by disc and ring infiltrometers, a review and recent developments. Soil Tillage Res., 55:1-29, 2000.

ANKENY, M.D.; AHMED, M.; KASPAR, T.C. \& HORTON, R. Simple field method for determining unsaturated hydraulic conductivity. Soil Sci. Soc. Am. J., 55:467-470, 1991.

AZOOS, R.H. \& ARSHAD, M.A. Soil infiltration and hydraulic conductivity under long-term no-tillage and conventional tillage systems. Can. J. Soil Sci., 76:143-152, 1996.

BAGARELLO, V.; ELRICK, D.E.; IOVINO, M. \& SGROI, A. A laboratory analysis of falling head infiltration procedures for estimating hydraulic conductivity of soils. Geoderma 135:322-334, 2006.

BAUMHARDT, R.L. \& LASCANO, R.J. Rain infiltration as affected by wheat residue amount and distribution in ridged tillage. Soil Sci. Soc. Am. J., 60:1908-1913, 1996.
BENJAMIN, J.G. Tillage effects on near-surface soil hydraulic properties. Soil Tillage Res., 26:277-288, 1993.

BLAKE, G.R. \& HARTGE, K.H. Bulk density. KLUTE, A., ed. Methods of soil analysis. Physical and Minerological Methods. 2.ed 1986. Part 1. p.363-376. (Agronomy Monograph, 8/9)

BODHINAYAKE, W.; SI, B.C. \& XIAO, C. New method for determining water-conducting macro- and mesoporosity from tension infiltrometer. Soil Sci. Soc. Am. J., 68:760$769,2004$.

BODNER, G.; SCHWEN, A.; SCHOLL, P.; KAMMERER, G.; BUCHAN, G.; KAUL, H-P. \& LOISKANDL, W. Characterization of tillage effects on soil permeability using different measures of macroporosity derived from tension infiltrometry. Geophys. Res. Abstr., 2010. (Abstract, 15334)

BOLLIGER, A.; MAGID, J.; AMADO, T.J.C.; SKORA NETO, F.; RIBEIRO, M.F.S.; CALEGARI, A.; RALISCH, R. \& DE NEERGAARD, A. Taking stock of the Brazilian "zero-till revolution": A review of landmark research and farmers' practice. Adv. Agron., 91:47-109, 2006.

CAMEIRA, M.R.; FERNANDO, R.M. \& PEREIRA, L.S. Soil macropore dynamics affected by tillage and irrigation for a silty loam alluvial soil in southern Portugal. Soil Tillage Res., 70:131-140, 2003.

COSTANTINI, A.; DE-POLLI, H.; GALARZA, C.; PEREYRA ROSSIELLO, R. \& ROMANIUK, R. Total and mineralizable soil carbon as affected by tillage in the Argentinean Pampas. Soil Tillage Res., 88:274-278, 2006.

COSENTINO, D.J. \& PECORARI, C. Limos de baja densidad: impacto sobre el comportamiento físico de los suelos de la región pampeana. Ci. Suelo, 20:9-16, 2002.

DÍAZ-ZORITA, M.; DUARTE, G.A. \& GROVE, J.H. A review of no till systems and soil management for sustainable crop production in the subhumid and semiarid Pampas of Argentina. Soil Tillage Res., 65:1-18, 2002.

ELISSONDO, E.; COSTA, J.L.; SUERO, E.; FABRIZZI, K.P. \& GARCÍA, F. Evaluación de algunas propiedades físicas de suelos luego de la introducción de labranzas verticales en un suelo bajo siembra directa. Ci. Suelo, 19:11-19, 2001.

FABRIZZI, K.P.; GARCÍA, F.O.; COSTA, J.L. \& PICOTE, L.I. Soil water dynamics, physical properties and corn and wheat responses to minimum and no-tillage systems in the southern Pampas of Argentina. Soil Tillage Res., 81:57-69, 2005.

FERRERAS, L.A.; COSTA, J.L.; GARCÍA, F.O. \& PECORARI, C. Effect of no-tillage on some soil physical properties of a structural degraded Petrocalcic Paleudoll of the southern "Pampa" of Argentina. Soil Tillage Res., 54:31-39, 2000.

GEE, G.W. \& BAUDER, J.W. Particle-size analysis. DANE, J.H. \& TOPP, G.C., eds. Methods of soil analysis. Physical and Minerological Methods. 2.ed. Madison, 1986. Part 1. p.383-411. (Agronomy Monograph, n.9)

GREEN, T.R.; AHUJA, L.R. \& BENJAMIN, J.G. Advances and challenges in predicting agricultural management effects on soil hydraulic properties. Geoderma, 116:3-27, 2003. 
HILLEL, D. Environmental soil physics. London, Academic Press, 1998. p.173-201.

HORNE, D.J.; ROSS, C.W. \& HUGHES, K.A. Ten years of a maize/oats rotation under three tillage systems on a silt loam in New Zealand. A comparison of some soil properties. Soil Tillage Res., 22:131-143, 1992.

HORTON, R.; ANKENY, M.D. \& ALLMARAS, R.R. Effects of compaction on soil hydraulic properties. In: SOANE, B.D. \& van OUWERKERK, C., eds. Soil compaction in crop production. New York, Elsevier, 1994. p.141-165.

IUSS Working Group WRB. World reference base for soils resources. Rome, FAO, 2006.

JARVIS, N.J. \& MESSING, I. Near-saturated hydraulic conductivity in soils of contrasting texture measured by tension infiltrometers. Soil Sci. Soc. Am. J., 59:27-34, 1995.

KASSAM, A.; FRIEDRICH, T.; SHAXSON, F. \& PRETTY, J. The spread of conservation agriculture: Justification, sustainability and uptake. Inter. J. Agric. Sustain., 7:292-320, 2009.

KAY, B.D. \& VANDENBYGAART, A.J. Conservation tillage and depth stratification of porosity and soil organic matter. Soil Tillage Res., 66:107-118, 2002.

LAL, R.; REICOSKY, D.C. \& HANSON, J.D. Evolution of the plow over 10000 years and the rationale for no-till farming. Soil Tillage Res., 93:1-12, 2007.

LOGSDON, S.D. \& JAYNES, D.B. Methodology for determining hydraulic conductivity with tension infiltrometers. Soil Sci. Soc. Am. J., 57:1426-1431, 1993.

MALONE, R.W.; LOGSDON, S.; SHIPITALO, M.J.; WEATHERINGTON-RICE, J.; AHUJA, L. \& MA, L. Tillage effect on macroporosity and herbicide transport in percolate. Geoderma, 116:191-215, 2003.

MORET, D. \& ARRÚE, J.L. Dynamics of soil hydraulic properties during fallow as affected by tillage. Soil Tillage Res., 96:103-113, 2007.

PERROUX, K.M. \& WHITE, I. Designs for disc permeameters. Soil Sci. Soc. Am. J., 52:1205-1215, 1988.

QUIROGA, A.; ORMEÑO, O. \& PEINEMANN, N. Efectos de la siembra directa sobre las propiedades físicas de los suelos. In: PANIGATTI, J.; MARELLI, H.; BUSCHIAZZO, D. \& GIL, R., eds. Siembra directa. Buenos Aires, Hemisferio Sur, 1998. p.237-243.

ROSS, C.W. \& HUGHES, K.A. Maize oats forage rotation under three cultivation systems, 1978-1983. 2. Soil properties. New Zealand J. Agric. Res., 28:209-219, 1985.
SANZANO, G.A.; CORBELLA, R.D.; GARCÍA, J.R. \& FADDA, G.S. Degradación física y química de un Haplustol típico bajo distintos sistemas de manejo de suelo. Ci. Suelo, 23:93-100, 2005.

SASAL, M.C.; ANDRIULO, A.E. \& TABOADA, M.A. Soil porosity characteristics and water movement under zero tillage in silty soils in Argentinean Pampas. Soil Tillage Res., 87:9-18, 2006.

SOKAL, R.R. \& ROHLF, F.J. Biometry. New York, Freeman, 1995. 887p.

SORACCO, C.G.; LOZANO, L.A.; SARLI, G.O.; GELATI, P.R. \& FILGUEIRA, R.R. Anisotropy of saturated hydraulic conductivity in a soil under conservation and no-till treatments. Soil Tillage Res., 109:18-22, 2010.

STEINBACH, H.S. \& ÁLVAREZ, R. Changes in soil organic carbon contents and nitrous oxide emissions after introduction of no-till in Pampean agroecosystems. J. Environ. Qual., 35:3-13, 2006.

STEINBACH, H.S. \& ÁLVAREZ, R. Afecta el sistema de labranza las propiedades físicas de los suelos de la región pampeana? Infor. Agron. Cono Sur, 33:7-12, 2007.

STRUDLEY, M.W.; GREEN, T.R. \& ASCOUGH II, C.A. Tillage effects on soil hydraulic properties in space and time: State of the science. Soil Tillage Res., 99:4-48, 2008.

THOMAS, G.A.; TITMARSH, G.W.; FREEBAIRN, D.M. \& RADFORD, B.J. No-tillage and conservation farming practices in grain growing areas of Queensland: A review of 40 years of development. Austr. J. Exper. Agric., 47:897$898,2007$.

USDA. Keys to soil taxonomy. 10.ed. Washington, 2006. 332p.

WAHL, N.A.; BENS, O.; BUCZKO, U.; HANGEN, E. \& HÜTTL, R.F. Eûects of conventional and conservation tillage on soil hydraulic properties of a silty-loamy soil. Phys. Chem. Earth, 29:821-829, 2004.

WALKLEY, A. \& BLACK, I.A. An examination of the Degtjareff method for determining organic carbon in soils: Effect of variations in digestion conditions and of inorganic soil constituents. Soil Sci., 63:251-263, 1934.

WATSON, K. \& LUXMOORE, R. Estimating macroporosity in a forest watershed by use of a tension infiltrometer. Soil Sci. Soc. Am. J., 50:578-582, 1986.

WILSON, G.V. \& LUXMOORE, R.J. Infiltration, macroporosity and mesoporosity distributions on two forested watersheds. Soil Sci. Soc. Am. J., 52:329-335, 1988. 
